\title{
Prolonged incubation in the two-colour immunofluorescence test increases the prevalence and titres of islet cell antibodies in Type 1 (insulin-dependent) diabetes mellitus
}

\author{
M. Landin Olsson ${ }^{1}$, G. Sundkvist ${ }^{1}$ and $\AA$. Lernmark ${ }^{1,2}$ \\ ${ }^{1}$ Department of Medicine, University of Lund, Malmö General Hospital, Malmö, Sweden and \\ ${ }^{2}$ Hagedorn Research Laboratory, Gentofte, Denmark
}

\begin{abstract}
Summary. The conventional indirect immunofluorescence test of islet cell antibodies was recently improved by the development of a two-colour immunofluorescence assay using a monoclonal proinsulin antibody to detect islet $B$ cells. The aim of this study was to test whether in this new assay the prevalence and titre of ICA were affected by the time of incubation carried out in the presence of aprotinin (Trasylol) as an inhibitor of proteolysis. The end-point titre of ICA was therefore determined in sera from 70 children aged 0.6 to 15 years with recent onset Type 1 (insulin-dependent) diabetes mellitus, 50 healthy control subjects and 97 non-diabetic siblings of Type 1 diabetic children. In the conventional twocolour assay, ICA was positive in 53/70 (76\%) Type 1 diabetic patients, $1 / 50$ control subjects and 2/97 siblings after $30 \mathrm{~min}$ incubation. Prolonged incubation for $18 \mathrm{~h}$ increased the prevalence of ICA positive samples to $62 / 70(89 \%)$ in the diabetic patients and to $2 / 50$ in the control subjects, while
\end{abstract}

the prevalence among the siblings was unchanged. Of the ICA positive non-diabetic subjects, one control child has a father with Type 1 diabetes, and one of the siblings subsequently developed Type 1 diabetes. In the diabetic patients the median titre was $1: 32$ for the 30 min incubation, and it increased to $1: 64$ for the $18 \mathrm{~h}$ incubation $(p<0.001)$. A marked prozone effect was seen; $16 \%$ of the samples from the Type 1 diabetic children sera were negative at a $1: 2$ dilution, but were found positive at higher dilutions. In conclusion, an $18 \mathrm{~h}$ incubation increases the end point titres and the prevalence of ICA in the two-colour ICA assay in Type 1 diabetic children of recent onset. The prevalence and levels of ICA among these patients may be larger than hitherto expected.

Key words: ICA, diabetes, indirect immunofluorescence, autoimmunity.
Islet cell antibodies (ICA), first described in 1974 [1, 2] by an indirect immunofluorescence one-colour assay, are thought to be a marker for Type 1 diabetes. The prevalence of ICA in Type 1 diabetic children at the time of diagnosis or within recent clinical onset varies from $51-85 \%$ [3-11]. Besides differences in patient selection, this variation in prevalence of ICA might be explained by differences in sensitivity between ICA assays $[12,13]$. Early attempts to quantitate ICA were inconclusive [4], and little attention has been paid to a possible relationship between levels of ICA and the progression of Type 1 diabetes. Recently, one study reported a positive correlation between complement-fixing ICA (CF-ICA) and preservation of B-cell function [10], while another [14] found a positive correlation between the titre of ICA at diagnosis and the rate of loss of pancreatic B-cell function evaluated by fasting Cpeptide during the first 2.5 years of insulin therapy. However, ICA may occur up to 8 years before the clinical onset of Type 1 diabetes [15]. The presence of ICA during a prediabetic period suggests that these antibodies might be directly associated with pancreatic Bcell destruction or serve as a marker for previous destructive events. Accordingly, determination of ICA might be used in screening attempts to find individuals at risk to develop Type 1 diabetes. If the ICA titre is to be employed as a prognostic test in prediabetic and Type 1 diabetic patients, the determination of titre levels requires an accurate and reproducible method.

Recently, we reported an accurate two-colour immunofluorescence ICA assay which substantially reduces the risk for false negative ICA reactions [16]. It has been suggested that a prolonged incubation with a protease inhibitor improves the sensitivity of the conventional one-colour ICA assay [17].

We have therefore evaluated the effect of incubation time on the ICA levels detected in the two-colour immunofluorescence assay. The aims of our study were to find the optimal time for incubation and to determine the prevalence and levels of ICA in recently diag- 
Table 1. Physical characteristics and islet cell antibodies (ICA) in Type 1 diabetic children, control children and non-diabetic siblings of Type 1 diabetic patients

\begin{tabular}{|c|c|c|c|}
\hline Group & $\begin{array}{l}\text { Type } 1 \text { diabetic } \\
\text { children }\end{array}$ & $\begin{array}{l}\text { Control } \\
\text { subjects }\end{array}$ & Siblings \\
\hline Number & 70 & 50 & 97 \\
\hline \multicolumn{4}{|l|}{ Age (years) } \\
\hline Median & 10 & 8 & 16 \\
\hline Range & $0.6-15$ & $0.3-15$ & $10-27$ \\
\hline \multicolumn{4}{|l|}{ Sex } \\
\hline Male/Female & $32 / 38$ & $22 / 28$ & $52 / 45$ \\
\hline \multicolumn{4}{|c|}{$\begin{array}{l}\text { Duration of insulin } \\
\text { therapy (days) }\end{array}$} \\
\hline Median & 1 & - & - \\
\hline Range & $-1-28$ & - & - \\
\hline \multicolumn{4}{|c|}{ Prevalence of ICA } \\
\hline $30 \mathrm{~min}$ & $53 / 70(76 \%)$ & $1 / 50(2 \%)$ & $2 / 97(2 \%)$ \\
\hline $18 \mathrm{~h}$ & $62 / 70(89 \%)$ & $2 / 50(4 \%)$ & $2 / 97(2 \%)$ \\
\hline \multicolumn{4}{|l|}{ Titres of ICA } \\
\hline $30 \mathrm{~min}$ & $1: 32$ & neg & neg \\
\hline $18 \mathrm{~h}$ & $1: 64^{a}$ & neg & neg \\
\hline \multicolumn{4}{|l|}{ Range } \\
\hline $30 \mathrm{~min}$ & neg $-1: 1000$ & neg $-1: 4$ & neg $-1: 64$ \\
\hline $18 \mathrm{~h}$ & neg $-1: 200000$ & neg $-1: 64$ & neg $-1: 512$ \\
\hline Prozone effect & $11 / 70(16 \%)$ & $1 / 50(2 \%)$ & $0 / 97(0 \%)$ \\
\hline
\end{tabular}

${ }^{a} p<0.001$ by Wilcoxon signed rank test for the difference of ICA end-point titres between 30 -min and 18 -h incubation assay

nosed Type 1 diabetic children, in order to validate the two-colour immunofluorescence ICA assay in future attempts to detect individuals at risk to develop Type 1 diabetes.

\section{Subjects and methods}

\section{Subjects}

In a first series of experiments, randomly collected serum samples from 30 recent onset Type 1 diabetic children aged 2-16 years (mean 9.9 years $\pm 4.4 \mathrm{SD}$, median 10.5 years) were analysed to establish the kinetics of ICA binding to its antigen. In a second series of experiments we analysed consecutively collected sera from 70 Type 1 diabetic patients aged $0.6-15$ years (mean 9.0 years $\pm 4.3 \mathrm{SD}$, median 10 years) who were diagnosed at different pediatric departments in Sweden (Table 1). These serum samples were obtained within one month after the initiation of insulin therapy. A first control group consisted of 50 children aged $0.3-15$ years (mean 7.9 years $\pm 4.6 \mathrm{SD}$, median 8 years) selected at random. All 50 control subjects answered a questionnaire regarding chronic diseases, autoimmunity or infections. All control subjects were included despite reported disease among themselves or their first degree family members. A second control group consisted of 97 non-diabetic siblings of Type 1 diabetic children aged 10-27 years (mean 16.1 years $\pm 4.8 \mathrm{SD}$, median 16 years) (Table 1). All serum samples were collected and stored at $-20^{\circ} \mathrm{C}$ or $-70^{\circ} \mathrm{C}$ for up to 30 months before analysis.

\section{Methods}

Cryostat sections of unfixed frozen human pancreas of cadaveric kidney donors of blood group 0 were used in the indirect two-colour immunofluorescence assay [16]. Two different pancreata were used throughout all the assays, one to test the diabetic children and the control subjects and another to test the siblings. Frozen sections were cut 1-3 $\mu \mathrm{m}$ thin and put on slides. The sections were allowed to dry and either incubated directly or stored at $-70^{\circ} \mathrm{C}$. Stored sections were dried with a fan for $30 \mathrm{~min}$ before use. In the first incubation, $25 \mu \mathrm{l}$ serum diluted in phosphate buffered saline (PBS) containing the monoclonal proinsulin (GS9A8) antibody [18] in a final dilution of $1: 1000$ was added as described previously [16]. The first incubation was performed in a dark moist chamber either at room temperature for $30 \mathrm{~min}$ or at $+4^{\circ} \mathrm{C}$ for $18 \mathrm{~h}$ or $24 \mathrm{~h}$. Aprotinin (Trasylol, Bayer AG, Leverkusen, FRG), $0.47 \mathrm{mg} / \mathrm{ml}$, was added to prevent proteolytic degradation of the pancreatic tissue [17]. Aprotinin did not affect end point titres of ICA in the 30-min incubation assay at room temperature (data not shown). After the first incubation the slides were washed in PBS three times each for $5 \mathrm{~min}$. Excess PBS was wiped off and the sections incubated with $25 \mu \mathrm{l}$ of a mixture of the two fluorescent second antibodies. Texas red labelled sheep antimouse IgG (N 2031, species specific, Amersham, Buckinghamshire, UK) was used to visualize the monoclonal proinsulin antibody and fluorescein isothiocyanate (FITC) conjugated rabbit anti-human IgG (Code F 202, Dako, Copenhagen, Denmark) to detect bound ICA. Undiluted FITC-labelled anti-human $\operatorname{IgG}$ and Texas red labelled anti-mouse IgG were centrifuged separately at $100000 \mathrm{~g}$ (Beckman Airfuge, Palo Alto, Calif, USA) for 5-10 min immediately before use, and were then mixed in equal proportions to give a final $1: 20$ dilution of each antibody. Before centrifugation and mixing, 9 parts undiluted FITC-labelled anti-human IgG was absorbed to one part mouse $\mathrm{IgG}$ covalently bound to agarose (Jackson, Immuno Research, Avondale, Penn, USA) by shaking at $+4^{\circ} \mathrm{C}$ in the dark for $60 \mathrm{~min}$. The agarose was then pelleted by centrifugation at $8000 \mathrm{~g}$ for $1 \mathrm{~min}$, the supernatant fluid removed and the pellet of agarose beads centrifuged once more to allow more of unabsorbed FITC-labelled antibodies to be recovered. The second incubation was performed in a dark moist chamber for $30 \mathrm{~min}$ at room temperature. The slides were then washed three times in PBS for 5 min each and mounted in glycerol TRIS $\mathrm{HCl}$ (pH 8.4). Microscopic evaluation was done on coded slides in an Olympus fluorescence microscope with epi-illumination (Olympus BH 2) by at least two independent observers. The filters used were EY 455 (exciter) and O 515 (barrier) for the FITC fluorescence and EO 530 (exciter) and O590 (barrier) for the Texas red fluorescence.

Sera were diluted $1: 2,1: 4,1: 8$, etc. until ICA was no longer detected. The end point titre was defined as the highest titre of detectable ICA. In the prolonged incubations, all samples were first screened at dilutions $1: 2$ and $1: 64$. The negative sera were then retested at dilution 1:8; this avoided the possibility that high titre positive sera which were negative at a low dilution would be recorded as negative. The positive sera were further tested to decide end-point titre. By this procedure all sera were tested in at least two different assays.

In each assay one positive standard sample in five different dilutions and one negative sample in three dilutions were included as quality controls. The end-point titre of the positive standard sera was recorded to determine interassay variation.

In seven sera of different end-point titres the ICA titres did not decrease when absorbed overnight at $+4^{\circ} \mathrm{C}$ to $1 \mu \mathrm{g} / \mathrm{ml}$ human recombinant DNA insulin (Humulin Regular, Eli Lilly, Indianapolis, Ind, USA). The insulin absorption was performed to exclude a possible influence of insulin autoantibodies on the ICA immunofluorescence reaction.

\section{Statistical analysis}

Wilcoxon signed rank test was used to test differences in end-point titres between results obtained for the different times of incubations. Fisher's exact test was used to test difference in ICA prevalence between 30-min and 18-h incubation assay in the group of 70 Type 1 diabetic children. All tests were two-tailed. All data are presented as median and range. The standard deviation was calculated for the positive quality sample to get the interassay variation. 

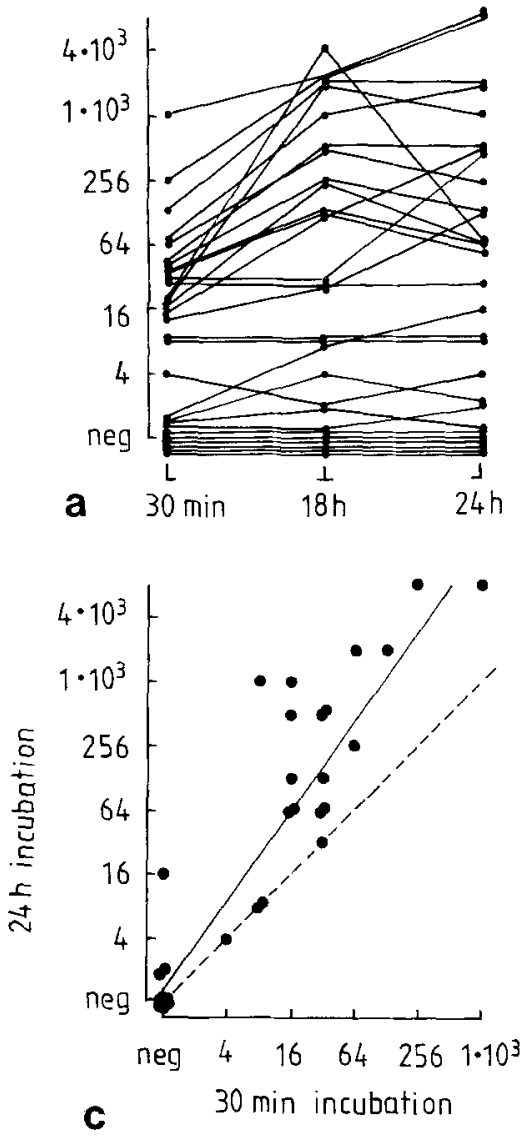
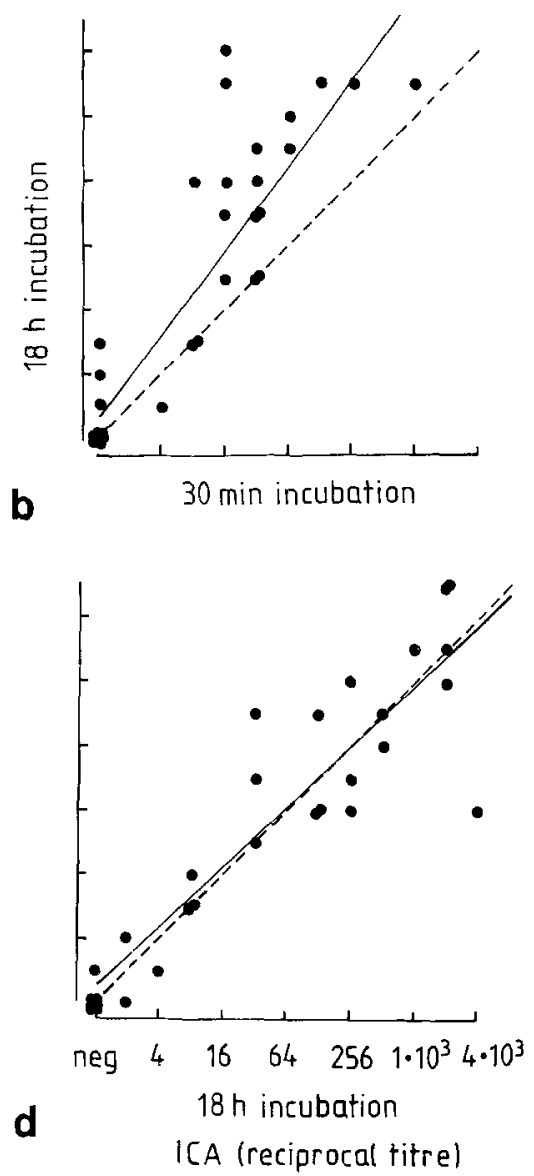

Fig. 1a-d. Islet cell antibodies (ICA) incubated for $30 \mathrm{~min}, 18 \mathrm{~h}$ and $24 \mathrm{~h}$ from 30 Type 1 diabetic children. a ICA at different times of incubation. b ICA titres when 30-min and 18-h incubation were compared. The solid line indicates the regression line and the broken line indicates the ideal line of total correlation. c ICA titres in the 30-min and 24-h incubation were compared; solid line $=$ regression line and broken line $=$ line of identity. d ICA titres when 18 -h and 24-h incubation were compared; solid line $=$ regression line and broken line $=$ line of identity.

\section{Results}

In the first series of experiments, sera from 30 Type 1 diabetic patients were incubated for $30 \mathrm{~min}, 18 \mathrm{~h}$ and $24 \mathrm{~h}$ (Fig.1). In the $30 \mathrm{~min}$ assay 20 samples were ICA positive, while in the two prolonged incubations ICA positivity increased to 23 samples. The median ICA end-point titre, which was $1: 16$ for the $30 \mathrm{~min}$ incubation, increased significantly to $1: 32(p<0.001)$ after $18 \mathrm{~h}$ incubation and to $1: 64(p<0.001)$ after 24 -h incubation. However, since there was no significant difference in end-point titre between the 18-h and the 24-h assay $(p<0.6)$, the $18-h$ assay was used in the further analysis.

In the second series of experiments, sera from 70 Type 1 diabetic children sampled very close to diagnosis were analysed to compare ICA end-point titres in the $30-\mathrm{min}$ and $18-\mathrm{h}$ incubations. In this series a control group of 50 children and 97 siblings of diabetic children were analysed as well. In the Type 1 diabetic group, $62 / 70(89 \%)$ were ICA positive, with a median titre of $1: 64$ in the $18-\mathrm{h}$ assay, compared to $53 / 70$ (76\%) ICA positive patients, with a median titre of $1: 32$ in the 30 -min assay. The difference in prevalence by Fisher's exact test (two-tailed) was 0.076 . Excluding the negative samples in each assay, it was found that the median ICA titre increased to $1: 64$ in the 30 -min assay and to $1: 128$ in the 18 -h assay $(p<0.001)$. In the

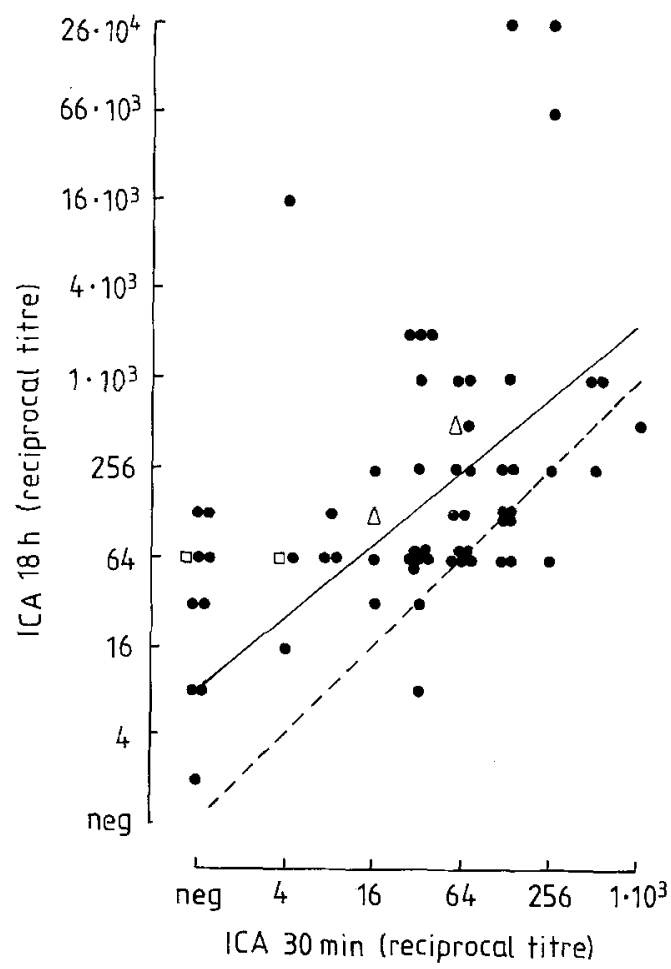

Fig. 2. Islet cell antibody (ICA) titres in sera from recent onset Type 1 diabetic children ( ), control subjects ( $\square$ ) and siblings of diabetic children $(\Delta)$. The prevalence of ICA in 18-h incubation assay was $62 / 70$ in diabetic children, $2 / 50$ in the control subjects and $2 / 97$ in the siblings of diabetic children 


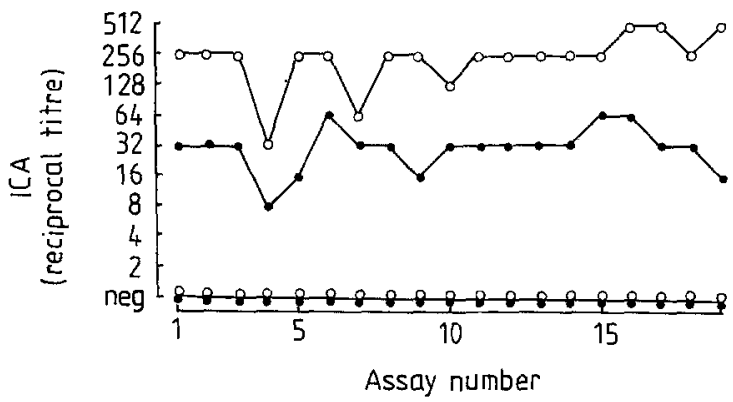

Fig. 3. The end-point titre or the highest properly evaluable positive titre of the constant positive standard sera both for $30 \mathrm{~min}(\mathbf{O})$ and for $18 \mathrm{~h}(\mathrm{O})$ for every assay. The ICA negative standard sera was found negative in all assays

control group $2 / 50$ were ICA positive in the 18 -h assay and one of them also was positive in the 30 -min assay (Fig. 2). The control child positive only in the 18-h incubation, with a titre of $1: 64$, was adopted from Thailand. Possible hereditary diseases are unknown. The other ICA positive control child had a titre of $1: 64$ in the 18-h and 1:4 in the 30-min assay; he is healthy, but his father has Type 1 diabetes. Among the siblings one girl was ICA positive, with a titre of $1: 128$ in the 18 -h and with $1: 16$ in the 30 -min assay. One boy was ICA positive, with a titre of $1: 512$ in the 18 -h and 1:64 in the 30 -min assay. More than 2 years after the blood sample was analyzed, this boy developed Type 1 diabetes.

ICA assay reproducibility and precision are rarely reported. ICA positive and negative quality control serum samples were therefore included in each assay at different dilutions. At the completion of this study, cumulated end-point titres of the quality control samples were plotted to visualize the interassay variation (Fig. 3). The positive control serum had a median titre of $1: 32$ with a standard deviation of 0.74 titration steps for 30-min and for 18-h incubation the median titre was $1: 256$ and the standard deviation was 0.92 titration steps. The negative samples were found negative in every assay.

All samples were tested at $1: 2$ and 1:64 dilutions to identify possible positive samples before the final titration. The negative samples were analysed a second time in 1:8 dilution. In the group of 70 newly diagnosed Type 1 diabetic subjects, it was revealed that ICA positivity was not always observed at a $1: 2$ dilution but was observed at higher dilutions. This phenomenon, usually referred to as a prozone effect, was observed in the 30-min assay, but was most pronounced in the 18 -h assay, where it occurred in 11 out of 70 samples $(16 \%)$. The prozone positive samples had end-point titres between 1:8 and 1:260000, with the median titre $1: 64$.

The addition of human insulin to neutralize possible insulin autoantibodies prior to the ICA analysis did not decrease ICA end-point titres (data not shown).

\section{Discussion}

Recently we have shown that the two-colour immunofluorescence assay to determine ICA is a reproducible test which correlates closely to the conventional onecolour ICA assay [16]. A major advantage of the twocolour assay is the possibility to first identify the islet $B$ cells and then to check whether these cells show ICA immunofluorescence. This procedure diminishes the risk of obtaining false negative ICA results, and it allowed us in one serum to identify ICA which did not stain the B cells. Counter-staining with glucagon antibodies showed this serum to contain ICA reactive with the A cells. In this study, we show that a prolonged incubation increases the end-point titres in recently diagnosed Type 1 diabetic patients, and thus confirms previous observations in the one-colour ICA assay [17]. A careful investigation of different incubation times revealed that the antibody-antigen equilibrium was reached after 18-h incubation. In comparison to the conventional 30-min assay, the mean titre of the ICA positive samples increased by about two titration steps after 18-h incubation. The higher sensitivity of the 18-h ICA assay increased the prevalence of ICA among 70 consecutively newly diagnosed Type 1 diabetic patients. This increase in ICA prevalence and titres were not due to aprotinin itself, since experiments with and without aprotinin in the $30-\mathrm{min}$ incubation assay showed that the mere presence of aprotinin did not influence ICA titres. Therefore, time of incubation to allow maximal antibody binding rather than aprotinin was responsible for the increased sensitivity of the 18-h ICA assay. If the prolonged incubation was performed without aprotinin, the tissue could not be properly evaluated because of the proteolytic damage.

The recent attempts to standardize the ICA analysis $[12,13]$ showed that there was a marked variation between different laboratories in the sensitivity of the conventional one-colour 30-min ICA assay. The importance of a reproducible assay for prognostic studies is evident. We demonstrate that the 18 -h two-colour assay shows a low interassay variation (Fig. 3), by repeated determination of the end-point titre of a positive and a negative standard sample. In our ICA assay the end-point titre of the positive quality control sera varied by only 0.92 titration steps, and there was no drift in the ICA assay.

An important and unexpected finding was the observation that up to $16 \%$ of the sera were negative at the $1: 2$ dilution, although positive at higher dilutions. This phenomenon, commonly referred to as a prozone effect, is thought to be dependent on an excess of antibodies inhibiting both the normal antigen-antibody binding and also the accessibility of the second antibody to react with the first antibody. This effect was especially pronounced in the prolonged incubations. It therefore becomes necessary to screen all samples at various levels of dilutions. It remains to be determined 
Table 2. Prevalence of islet cell antibodies (ICA) among children and young adults with recent onset Type 1 diabetes in studies reporting ICA within the first year following diagnosis

\begin{tabular}{|c|c|c|c|c|c|}
\hline \multicolumn{2}{|l|}{ Reference } & \multirow{2}{*}{$\begin{array}{l}\begin{array}{l}\text { Age of } \\
\text { patients } \\
\text { (years) }\end{array} \\
1-17\end{array}$} & \multirow{2}{*}{$\begin{array}{l}\begin{array}{l}\text { Duration } \\
\text { of insulin } \\
\text { therapy }\end{array} \\
<1 \text { year }\end{array}$} & \multicolumn{2}{|c|}{$\begin{array}{l}\text { Prevalence } \\
\text { ICA } \\
\text { positive }\end{array}$} \\
\hline endrum & (1975) (3) & & & $51 / 101$ & $(510)$ \\
\hline Lendrum & (1976) (4) & average 18 & $0-1 \mathrm{w}$ & $17 / 20$ & $(85$ \\
\hline Irvine & (1977) (5) & $0-9$ & $<1$ year & $13 / 21$ & $(62 \%)$ \\
\hline Betterle & $(1980) \quad(6)$ & $1-49$ & $0-1$ year & $62 / 91$ & $(68 \%)$ \\
\hline Lernmark & (1981) (7) & $1-16$ & 0 days & $22 / 33$ & $(67 \%)$ \\
\hline Kobayashi & (1983) (8) & $(34 \pm 17)$ & $0-1$ yea & $11 / 19$ & $(58 \%)$ \\
\hline Bruining & (1984) (9) & $3-17$ & $0-3$ months & $20 / 25$ & $(80 \%)$ \\
\hline Mustonen & (1984) (10) & $0.7-16.7$ & $0-10$ weeks & $37 / 44$ & $(84 \%)$ \\
\hline Takahashi & $(1986)^{a}(11)$ & not given & $<1$ year & $17 / 20$ & $(85 \%)$ \\
\hline
\end{tabular}

a Peroxidase-labelled protein $\mathrm{A}$

whether the prozone positive samples are always of high titres. If so, the prozone effect could be the explanation why sera are sometimes reported negative for ICA but positive in the complement-fixing-ICA (CFICA) assay [19], which has been found to be a less sensitive assay $[12,13]$.

The finding of insulin autoantibodies (IAA) in newly diagnosed Type 1 diabetic children prior to insulin therapy has been reported up to $30 \%$ [20-24]. In the 30-min two-colour immunofluorescence ICA assay the end-point titres of ICA for IAA positive and ICA positive sera (IAA/ICA) correlated with those titres found in the conventional one-colour 30-min ICA assay, indicating that IAA and the proinsulin antibody do not interfere and have different antigenic sites [16]. It was therefore tested whether higher titres in the 18-h twocolour ICA assay could be due to IAA, by adding excess of human recombinant insulin to the sample to preabsorb possible IAA. However, this did not influence the ICA end-point titres. In fact, the titres tended to be higher in the presence of insulin.

In the present study, $89 \%$ of the patients with recent onset Type 1 diabetes were ICA positive in the 18 -h assay compared to $76 \%$ in the $30-\mathrm{min}$ assay. When our results are compared to those previously reported (Table 2), the present ICA prevalence is higher than in most other materials. One explanation may be the short latency from time of diagnosis to serum sampling, since the titre $[12,13]$ and prevalence $[3,5,7]$ of ICA decrease with increasing duration of Type 1 diabetes. However, the main reason for the high prevalence of ICA in our study is likely to be the increased possibility of detecting islet cell antibodies in the 18-h assay. Titrations of ICA are of interest because a positive correlation between ICA levels and the rate of decrease in fasting C-peptide was found in Type 1 diabetic patients prospectively observed throughout a 2.5 year period [14]. If this phenomenon is also to be substantiated in future studies of ICA positive nondiabetic individuals, a wide range of titres would seem preferable. The 18-h two-colour assay (Fig. 2) showed not only an increase in the median titre among the diabetic patients but also in the range of titres. Hitherto not reported, remarkably high titres $\left(>2 \times 10^{5}\right)$ were found in some patients. The prolonged incubation therefore made it possible to more clearly delineate the ICA positive from the ICA negative group of diabetic individuals. This was also apparent among control subjects and siblings. The two control subjects and the two siblings with ICA showed titres well within the range of the ICA positive Type 1 diabetic patients. One of the siblings has now developed Type 1 diabetes, more than 2 years after the sample was taken. He is also HLA-DR identical to his diabetic sibling. Although further analyses are necessary, this indicates that ICA titration in the 18-h two-colour immunofluorescence test may be of better predictive value for identifying prediabetic subjects than just recording whether the autoantibodies are present or not. Hence, we suggest that the prolonged ICA assay is suitable in screening attempts to detect individuals at risk to develop Type 1 diabetes. Since the prediabetic period may be long even among children, an age group which remains to be properly investigated, the present assay may better define individuals who have an active autoimmune process against the pancreatic islet cells. An early detection of prediabetic subjects will allow future tests of immune intervention or other measures in attempts to prevent a subsequent onset of the disease.

In conclusion, a prolonged incubation in the presence of aprotinin increases the sensitivity of the twocolour immunofluorescence test to determine ICA. In Type 1 diabetic patients, our 18-h two-colour immunofluorescence ICA assay demonstrates a wide range of ICA titres, increases the overall end-point titres of ICA, and clearly discriminates ICA positive from ICA negative serum samples.

Acknowledgements. We thank Ms. Delgado-Frohm for her skillful technical assistance. We thank our colleagues in the Children Diabetes Registry, in particular the coordinators Dr. Dahlqvist and Dr. Blom, and also Dr. Lindgren and Dr. Persson, who made sera from their study on siblings of diabetic children as well as newly diagnosed diabetic patients available to us. This study was supported by grants from the Malmö Diabetes Association, the Swedish Diabetes Association, the Swedish Medical Research Council (grant 19X07507 and 19I-07507) and the National Institutes of Health (grant AM 26190).

\section{References}

1. Bottazzo GF, Florin-Christensen A, Doniach D (1974) Islet cell antibodies in diabetes mellitus with autoimmune polyendocrine deficiencies. Lancet 2: 1279-1283

2. MacCuich AC, Irvine JW, Barnes EW, Duncan LJP (1974) Antibodies to pancreatic islet cells in insulin-dependent diabetics with coexistent autoimmune disease. Lancet 2: 1529-1531

3. Lendrum R, Walker G (1975) Islet-cell antibodies in juvenile diabetes mellitus of recent onset. Lancet 1: 880-883

4. Lendrum R, Walker $G$, Cudworth AG, Theophanides C, Pyke DA, Bloom A, Gamble DR (1976) Islet cell antibodies in diabetes mellitus. Lancet 2: 1273-1276 
5. Irvine WJ, McCallum CJ, Gray RS, Campbell CJ, Duncan LJP, Farquhar JW, Vaughan H, Morris PI (1977) Pancreatic islet-cell antibodies in diabetes mellitus correlated with the duration and type of diabetes, coexistent autoimmune disease, and HLA type. Diabetes 26: 138-147

6. Betterle C, Caretto A, Tiengo A, Trevisan A (1980) Complementfixing islet-cell antibodies in Type 1 diabetes and in susceptible patients with autoimmune diseases. Lancet 1: 1418-1419

7. Lernmark $\AA$, Hägglöf B, Freedman Z, Irvine J, Ludvigsson J, Holmgren G (1981) A prospective analysis of antibodies reacting with pancreatic islet cells in insulin-dependent diabetic children. Diabetologia 20: 471-474

8. Kobayashi T, Sawano S, Sugimoto T, Itoh T, Kosaka K, Tana$\mathrm{ka} T$, Suwa $S$ (1983) Islet-cell antibodies in IDDM and NIDDM in a Japanese population. Tohoku J Exp Med 141 [Suppl]: $271-274$

9. Bruining GJ, Molenaar J, Tuk CW, Lindeman J, Bruining HA, Marner B (1984) Clinical time-course and characteristics of islet cell cytoplasmic antibodies in childhood diabetes. Diabetologia 26: $24-29$

10. Mustonen A, Knip M, Huttunen N-P, Puukka R, Käär M-L, Åkerblom HK (1984) Evidence of delayed beta-cell destruction in Type 1 (insulin-dependent) diabetic patients with persisting complement-fixing cytoplasmic islet cell antibodies. Diabetologia 27: $421-426$

11. Takahashi A, Tsujihata M, Yokota A, Yamaguchi $Y$, Ueda $Y$, Akazawa S, Miyake S, Nagataki S (1986) A new method of detection of islet cell antibodies (ICA) using peroxidase-labeled protein A, and incidence of ICA in Type 1 (insulin-dependent) diabetes. Diabetologia 29: 378-382

12. Bottazzo GF, Gleichmann H (1986) Immunology and Diabetes Workshop: report of the first international workshop on the standardisation of cytoplasmic islet cell antibodies. Diabetologia 29: 125-126

13. Gleichmann H, Bottazzo GF (1987) Progress towards standardisation of the cytoplasmic islet-cell antibody assay: analysis of the data presented at the first international workshop. Diabetes (in press)

14. Marner B, Agner T, Binder C, Lernmark Å, Nerup J, MandrupPoulsen T, Walldorff $S$ (1985) Increased reduction in fasting Cpeptide is associated with islet cell antibodies in Type 1 (insulindependent) diabetic patients. Diabetologia 28: 875-880

15. Gorsuch AN, Spencer KM, Lister J, McNally JM, Dean BM, Bottazzo GF, Cudworth AG (1981) Evidence for a long pre-diabetic in type 1 (insulin-dependent) diabetes mellitus. Lancet 2: 1363-1365
16. Madsen OD, Landin Olsson M, Bille G, Sundkvist G, Lernmark $\AA$, Dahlqvist $G$, Ludvigsson J (1986) A two-colour immunofluorescence test with a monoclonal human proinsulin antibody improves the assay for islet cell antibodies. Diabetologia 29: $115-118$

17. Pilcher C, Elliott RB (1984) Improved sensitivity of islet cell cytoplasmic antibody assay in diabetics. Lancet 1: 1352

18. Madsen OD, Larsen LI, Lernmark $\AA$ (1985) Diffusion of C-peptide but not proinsulin from islets in frozen sections of human pancreas identified by monoclonal antibodies. Biomed Biochim Acta 44: 133-136

19. Bottazzo GF, Dean BM, Gorsuch AN, Cudworth AG, Doniach D (1980) Complement-fixing islet-cell antibodies in type 1 diabetes: possible monitors of active beta-cell damage. Lancet 1: 668-672

20. Palmer JP, Asplin CM, Clemons $\mathrm{P}$, Lyen $\mathrm{K}$, Tatpati $\mathrm{O}$, Raghu PK, Paguette TL (1983) Insulin antibodies in insulin-dependent diabetics before insulin treatment. Science 222: $1337-1339$

21. Wilkin T, Armitage M, Casey C, Pyke DA, Hoskins PJ, Rodier M, Diaz JL, Leslie RDG (1985) Value of insulin autoantibodies as serum markers for insulin-dependent diabetes mellitus. Lancet 1: 480-482

22. Arslanian SA, Becher DJ, Rabin B, Atchinson R, Eberhardt M, Cavender D, Dosman J, Drash AL (1985) Correlates of insulin autoantibodies in newly diagnosed children with insulin-dependent diabetes before insulin therapy. Diabetes 34: 926-930

23. Ludvigsson $\mathbf{J}$, Binder $\mathbf{C}(1985)$ The amount of insulin antibodies after insulin treatment is not related to insulin autoantibodies at onset of IDDM. Diabetes Res Clin Pract [Suppl 1]: 348

24. Atkinson MA, Maclaren NK, Riley WJ, Winter WE, Fisk DD, Spillar RP (1986) Are insulin autoantibodies markers for insulindependent diabetes mellitus? Diabetes 35: 894-898

Received: 9 December 1986

and in revised form: 16 March 1987

Dr. Mona Landin Olsson

Department of Medicine

University of Lund

Malmö General Hospital

S-21401 Malmö

Sweden 